\title{
Education for Street Children in Egypt: The Role of Hope Village Society
}

\author{
Muhammad M. Zain Al-Dien \\ Al-Azhar University, Egypt \\ drmmz75@yahoo.com
}

\begin{abstract}
The purpose of the present study is to evaluate the role of Hope Village Society (HVS) in Egypt in the provision of education to street children in order to establish its strengths and weaknesses to serve as lessons for other providers of education to street children. Data were collected using interview schedule and document analysis. Interviews were prepared conducted with eight of the management staff of HVS. The findings of the study reveal that HVS plays a major role in providing education for street children in Egypt. Since the establishment of HVS's education programs in 1995, it has recorded fluctuating enrolment rates. The participation of government organizations (GOs), non-government organizations (NGOs) and community at HVS' education programs is less than expected. Like any other educational enterprise, HVS's education programs are faced with quite a number of problems. The study recommends that the Egyptian government should offer more financial contributions to organizations that provide education to street children. There is also an immediate need to engage other possible partners of HVS's education programs. Moreover, more research should be carried out in the area of pedagogy of street children.
\end{abstract}

\section{Introduction}

One of the most conspicuous symbols of poverty is the growing presence of children on the street: children making a living by scavenging, hawking and soliciting while their peers are in school. They are now often part of the urban scene in developing countries. They represent a marginalized, vulnerable, and victimized segment of society. Their rights to protection and access to basic rights such as education, health, care and development are limited.

The United Nations estimates the population of children on the streets worldwide to be at 100 million, with the number rising daily. Of these, 20 million are in Africa; 40 million are in Latin America; 25-30 million in Asia; and 25 million in other parts of the world (UNICEF, 1999; Casa Alianza, 2002). At least one million children in Africa alone are being commercially sexually exploited in brothels, bars and on the streets. Many of them are doing difficult and dangerous jobs and are injured in serious accidents (Ennew, 1994).

Although homelessness is not yet seen as a major public problem in most African countries (Velis, 1995; Aina, 1997), children on the street are now being recognized as a social problem worthy of urgent attention in Egypt. Studies have attributed the causes of street children in Egypt to rapid urbanization, deteriorating economic conditions,

Journal of Contemporary Issues in Education, 2009, 4(1), pp. 37-56.

ISSN 1718-4770 (C) 2009 University of Alberta

http://ejournals.library.ualberta.ca/index.php/JCIE 
declining social programs and the weakening of family ties (Hussein, 1998; Koraim, 1998; Bibars, 1998).

Under current Egyptian law, street children fall under "children at high risk" and therefore can be arrested when found and placed in corrective institutions*. Surveys of these children have found that they range in age from nine to eighteen years of age, although the majority are around thirteen years of age. Most of these children are members of the local urban poor. However, some are older children that migrate from rural areas in the hope of finding employment. Many street children in Egypt have left families facing extreme forms of poverty. Many of these children do not attend school, do not receive health care, and are unprotected by adults. The trajectory that often leads children from poor families to resort to the streets involves poverty, dysfunctional family, child abandonment, and/or physical and sexual abuse. Some of these children live on the streets to escape violence at home and others are abandoned by their families who cannot afford to support them or are not available to do so because of death, imprisonment, or extreme sickness. Some resort to begging and pick pocketing because these are the only sources of income for their destitute families (ODCCP, 2002). 5

Although there are no official statistics on the magnitude of the street children problem in Egypt, some efforts have been made to estimate their number, regardless of accuracy or techniques used to ensure both validity and reliability. Sedik (1995), based on the records of HVS, estimated that the number of street children in Egypt, both males and females, to be 93,000. Others estimate that their number reached 2 million in 1999 (The General Egyptian Association for Child Protection, 1999).

Both primary and secondary data indicate that the reasons for the lack of valid and reliable data on the magnitude of the problem are based on many reasons. Firstly, there is difficulty connected with carrying out surveys due to the constant mobility of street children from one area to another and between major cities in Egypt. Secondly, the recent use of the term street children at both the academic and official levels, and the paucity of academic literature on the topic. Thirdly, various social and legal terms have been used to refer, not particularly to street children, but to all criteria of problematic children or children at risk, including juvenile delinquents, vagrants, and cases of exposure to delinquency. This makes it hard to determine the exact magnitude of the problem, hence the inability to accurately define the meaning of the term street children. The last reason is that official police and court records do not refer to the actual magnitude of the problem in Egypt, but rather to the total number of children who have been reached by the police and sent to social care juvenile institutions with a court order (ODCCP, 2002).

It is important to mention that the problem of street children in Egypt cannot be related to a single cause. Unlike the situation in other countries where a single factor such as extreme poverty, civil wars, or natural disasters might be the leading cause (Aina, 1997), the problem of street children in Egypt is multi-dimensional with a combination of factors often leading to a single child ending up on the street. Still, most research seems to agree that the leading causes of the problem include poverty, unemployment, family breakdown, child abuse and neglect, dropping out of schools, child labour, the effect of peers, and other social and psychological reasons related to the social environment or to the personality of the child such as behavioral disorders or sensation seeking (Abu El-

* The Child Law (12), 1996 
Nasr, 1992; Abdel Nabi, 1994; Sedik, 1995; Koraim, 1998; Bipars, 1998). Accordingly, the street children phenomenon is not solely a result of inefficiencies in the formal school system, but a product of a variety of factors.

Mobility of street children in most cases is greatly affected by urban and weather conditions. Cairo represented the main city in Egypt, which seems to attract the greatest number of street children. Statistics of cases of exposure to delinquency during the period (1987-1997) show that Cairo is attracting more street children (31.6 percent), followed by Port Said (16.8 percent), Suez (14.3 percent), and then Alexandria (6.3 percent) (Koraim, 1998). Because of the circumstances they are in, street children are faced with quite a number of problems such as violence, community disapproval, police arrests, robberies of savings, health problems, rape, prostitution, drug and malnutrition (Smith, 1997; Hlatshwayo,1997). Street children are therefore disadvantaged: they have no access to formal education, basic services or family affection and support. They are disfavored children with poor chances of having a decent future, condemned to live by deceit, stealing, prostitution or violence (Lusk, 1989; Young, 1995; Bernini, 1996; Caillods, 1998).

Education has become a lifelong process, with people learning at any age, and in any place, as needs and opportunities arise. Some learning opportunities are relatively unstructured and non-formal, but nevertheless provide meaningful experiences (Thomson, 2001). Street children's lack of access to education is therefore considered a violation of a fundamental human right: the right to education proclaimed in the 1948 Universal Declaration of Human Rights to the 1989 Convention on the Rights of the Child (UNICEF, 1999).

The United Nations Convention on the Rights of the Child has had a huge impact in defining conceptual frameworks and humanitarian concerns regarding children in adversity. The Convention asserted a number of rights for children worldwide, formulated basic principles to be applied, and created a legal obligation to put these rights and principles into practice. Concern for children in difficult circumstances was no longer a matter of humanitarian and charitable concern, but now is a legal responsibility falling on the state as part of the Convention (Panter-Brick, 2001). The Convention heralded a change in the prevailing discourse regarding street children and, more generally, children facing adversity. The emphasis moved significantly from highlighting the needs of vulnerable children to defending their rights as citizens (Moss et al., 2000).

It is not enough to simply insure that children attend school. The Convention on the Rights of the Child is clear: every child has the right to quality education that is relevant to his or her individual life and personal development. The Convention on the Rights of the Child's perspective on quality education encompasses not only children's cognitive needs, but also their physical, social, moral, emotional and spiritual development (UNICEF, 1999; ANPPCAN, 1995; The Children's Charter of South Africa, 1992).

Although the Egyptian government is obligated to provide education to all, many actors play vital roles in delivering it: from international agencies to local communities, non-governmental organizations (NGOs) and religious groups. Therefore, Egypt boasts of a number of NGOs that address the plight of street children. These NGOs include Hope Village Society, CARITAS, General Egyptian Association for Child Protection, AlHoria and Toufolti Association. Most of the programs that cater to street children by 
these NGOs have endeavored to respond to children's special needs, which include: educational programs, family reunion, substance abuse, emergency services, health programs, child rights and protection (ODCCP, 2002).

\section{Hope Village Society (HVS)}

HVS was established in 1988 as a NGO that cares for orphans and foundlings. The model adopted by HVS was similar to that adopted by the SOS Villages in terms of provision of full-residential care. HVS began tackling the problem of street children in 1990, by establishing a drop-in center in the area of Shoubra, a heavily populated area in the heart of Cairo, and a temporary shelter for street children in the area of Hadayek ElKoba, with a maximum capacity of 20 children. Then, with the help of various funding agencies, as well as various local funds, HVS began extending its programs and activities to deal with the phenomenon of street children. The model adopted by HVS in Egypt is still considered as one that other NGOs currently follow (ODCCP, 2002).

HVS identifies street children as those children who have considered the street as a shelter and a substitute for living with their families in order to meet their basic needs for food and survival, and who were driven to the street as a result of major family problems (Hope Village Society, 2006). The facilities of Hope Village for dealing with the problem of street children include, Shoubra reception center for boys, El-Sayda Zeinab reception center for boys, Roud Al-Farag reception center for girls, a temporary shelter in Hadayek El-Koba, a temporary shelter in Mukattam, 3 permanent shelters in Nasr City, 2 permanent shelters in the Tenth of Ramadan City and youth hostels. The staff working for HVS has exceeded 100 (whether full or part-timers), and includes the following areas of specialty: teachers, trainers (vocational and others), social workers and psychologists, physicians, dentists, accountants, and administrators. The programs implemented by HVS include: education programs which consist of "literacy education, recreational activities and vocational training," the provision of loans for the families of street children in return for keeping children within the family and educating them, family reconciliation, health programs, and community development. The model adopted by HVS is based on applying a number of activities aiming at dealing with the problem of street children, which include: using reception centers as main channels for establishing contact with street children, for the provision of temporary and permanent shelters for some of the children according to available spaces, and the provision of rehabilitation programs for children residents of shelters (Hope Village Society, 2006; ODCCP, 2002).

Thus, HVS is a pioneer provider of education to street children and therefore has the broadest experience within this group of society. It is against this background that the role played by HVS in providing education to street children has been examined in this study, with a view to articulate the lessons of HVS's experience. This may enable other NGOs to build on these lessons and benefit from it in order to optimize a collective response to the problem of street children.

\section{Research Questions}

The current study is guided by the following principal question: what is the role of HVS in the provision of education to street children in Egypt? Additionally, four specific sub-questions emerge from this fundamental question, namely: (a) what are the types of 
education offered by HVS to street children? (b) What are the enrolment trends at HVS's education programs? (c) Do these programs have linkages with other actors and institutions? (d) What constraints do these programs encounter in providing education to the street children?

\section{Review of Literature}

Three categories of literature are reviewed: street children, education for street children and NGOs providing Education for street children.

\section{Street Children}

The presence of children living on the street has elicited emotive public concern, been given considerable media coverage, and, in the late twentieth century, has become a matter of priority for national and international child welfare organizations. Publications in both academic and welfare literature have emphasized the sheer scale of the worldwide problem, sought to explain the root causes of this phenomenon, summarized the identifying characteristics of street children worldwide, and documented the dire consequences of a street life for children's health and development. Titles such as $A$ Growing Urban Tragedy (Agnelli, 1986), "Causes and Characteristics of the Street Child Phenomenon" (le Roux \& Smith, 1998), and "Homelessness is not Healthy for Children" (Wright, 1990) capture the essence of such concern.

The increased presence of street children has prompted various attempts to define them. A basic definition of the term "street children" is "a homeless or neglected child who lives chiefly in the streets" (Oxford Dictionary). The statement emphasizes two peculiarities about street children: the place they occupy and the absence of proper contacts or links with adults in the family home and in society. Dated definitions of street children can be differentiated into two categories: "children of the street" and "children on the street" (Ennew, 1994; Lusk, 1989). The former are those who live full time on the street and sleep there at night, while the latter are those who work on the street by day and return to a home base at night. Accordingly, street children include all children and youth for whom the street is the major player in their lives.

Dated definitions, such as children of and on the street, have been criticized for failing to embrace the wider domain of a street child's life including their occupation of family homes, institutions and NGOs, as well as street spaces (Connolly and Ennew, 1996; Ennew, 1994). Furthermore, as Glauser (1990) has argued, children on the street share much of the life of children of the street. Others have deemed the term 'street child' itself inappropriate because it is inextricably tied-up with negative perceptions of street children as criminals, prostitutes and drug addicts (Dallape, 1996). However, as Shanahan $(1998 ; 2003)$ asserts, the term 'street child' is not necessarily insulting for the children themselves.

In the review of various studies carried out in India on street children, Bose (1992, p. 48-52) observed that most street children: (a) are over the age of 6; (b) are boys, mainly because of the socio-cultural factors limiting young girls' mobility; (c) have never attended school and, a majority of those who do, drop out before completing school; (d) have close ties with their families and return to them after the day's activities; (e) their parents mainly hold low-paid, unskilled jobs or are self-employed; (f) work for a living, 
although this is more the case for boys than for girls; (g) work exclusively in the informal sector in jobs which do not require special skills, training or a sizeable capital investment; (h) their nutrition and health status is not at satisfactory levels; (i) are exposed to physical abuse and extortion and, although most are low abiding, in order to survive forces, some of them to engage in illegal activities; and (j) are engaged in daily survival scenarios and develop resourcefulness, self-reliance, and other survival skills for life in a hostile environment.

The turn of the twenty-first century has seen a sea of change in most of the writing concerning street youth. The term street children itself has almost disappeared from the welfare and analytical literature which now uses different appellations to refer to street children and other underprivileged groups. Children themselves, of course, are still on the streets, easily visible in the great majority of urban centers. What has been called the global or "worldwide phenomenon of street children" has neither vanished from sight nor effectively been solved (le Roux, 1996). However, current perspectives tend not to demarcate street children so radically from other poor children in urban centers or to conceptualize the homeless in isolation from other groups of children facing adversity. Welfare agencies now talk of "urban children at risk," which conceptualizes street children as one of a number of groups most at risk and requiring urgent attention (Boyden \& Mann, 2000; Kapadia, 1997).

One problem that appears in many of the discussions around street children in Egypt is on the definition of street children itself (Abu Al-Nasr, 1992). Generally, there are two broad main trends in defining street children in Egypt, one adopted by NGOs, researchers, and the media, and, another, a legal definition adopted by the Social Defense Department and various legislators that consider street children as "children exposed to delinquency." According to the former, street children are mainly defined as: children under age 18 (based on how childhood is legally defined in Egypt), males or females who spend all or most of their time on the street, who maintain minimal contact with their families or have no contact at all, and, who lack supervision, protection or guidance, which makes them vulnerable to a wide range of health and psychological hazards (Abu Al-Nasr, 1992; Hussein, 1998; Koraim, 1998; Sedik, 1995). Such definition is not based on the social or economic backgrounds of the children, or the types of activities they perform which are mostly viewed as survival behaviors for living, but rather on the physical contact with the street setting as compared to contact with their families.

The legal definition of street children seems to have long been affected by the correctional approach and the passive social outlook towards these children. Such a definition seems to be the functional/operational definition of street children at the governmental level. Street children in Egypt had historically been labeled and considered as vagrants, delinquents, juvenile delinquents, juveniles exposed to delinquency and, until recently, were recognized as children exposed to delinquency according to the Child Law. The Child Law of 1996 defines cases of exposure to delinquency on the basis of the types of activities children do which include if the child: (a) is found begging, or selling trivial items or performing shows on the street, or any other activities, which are not considered as positive resources for living; (b) collects cigarette ends or other items or things from wastes; (c) has any connection with prostitution, gambling or drugs; (d) has no permanent place to sleep, and usually sleeps on the street; (e) contacts those exposed to delinquency or suspects; (f) is accustomed to escaping from educational or vocational 
training institutions; ( $\mathrm{g}$ ) has bad behavior and is delinquent from his guardian (h) has no means to live and no trusted guardian; (i) is less than seven years of age and found in any of the previously mentioned cases of exposure to delinquency, or if the child commits one of the previously mentioned felonies; and (j) has a mental or a psychological disorder to the extent that he/she might cause harm to himself/herself or to others. In short, such inconsistency in defining the meaning and definition of street children in Egypt, and diversity between the definition of NGOs, researchers and the media, as compared to the legal definition of cases of exposure to delinquency which covers all criteria of children, and not particularly street children, have their impact on understanding the various dimensions of the problem and the consequence of its exact magnitude.

\section{Education for street children}

Learning in the twenty-first century requires equipping children with a basic education in literacy and numeracy, as well as in the more advanced skills for living that can serve as a foundation for life, enabling children to adapt and change according to life circumstances (Ennew, 1994). Good quality education is a must especially for programs that are interventionist such as those designed for children at risk.

Lusk (1989) observed that nothing contributes more to a loss of human development potential than a childhood and youth spent outside the framework of a family and school in the usually hostile environment of the street. Bennani (1996) and Smith (1997) have pointed out that although the best solution to the street children phenomenon would be to reunite them with their families, some children do not have homes or families to return to.

Among the known causes of the street children phenomenon is lack of access to, or dropping out from, school. The conventional education systems in many countries are too rigid to reach the children who, because of gender, ethnicity or poverty, do not have access to school. The challenge for schools is to be flexible enough to adapt the needs of disadvantaged children while offering education of sufficient quality to retain all children once they are in school (Brink, 2001; UNICEF, 1999).

Double shifting has been employed by education providers to improve access. Multi-grade teaching, in which children of two or more age groups are taught by the same teacher in the same classroom, the mobile teaching approach, and distance education, are other strategies that would enhance access to education. The hall mark for all these approaches is flexibility, by which the approaches are adapted to the local conditions in order to meet the educational needs of all the children (UNICEF, 1999).

Street education is a very effective way to support street children as it occurs at locations where they live. Educating street children involves helping them to acquire knowledge, skills and attitudes in specific areas of need (WHO, 2002). The main purpose of street children's education should not be limited to imparting information relevant for examinations, but rather to seek to provide education that is relevant to the children's impoverished circumstances and to the need they have to earn a living (Shorter and Onyancha, 1999).

During a workshop entitled "Hearing on street children in Kenya" organized by ANPPCAN (1995), the following recommendations were identified: (a) any education program for street children must be flexible. It must serve to rehabilitate and provide adequately for street children's physical, psychological and sociological needs. There has 
to be room for highly individualized programs that enable a given child to start at his or her own level of competence (determined by expert assessment); (b) in order to contain the street children phenomenon, adequate provisions should be made for children from poor families. Basic education should be made compulsory, and free, and alternative education programs should be designed for street children (The Children's Charter of South Africa, 1992); (c) the essential elements of street children's education should include literacy and vocational training with a strong dose of life-skills training that will help the child to develop into a self- reliant, productive and responsible citizen; and (d) schools should see themselves much more in terms of their community function: they must make greater efforts to retain children.

The 1992 Children's Charter of South Africa recognized the urgency to improve the lives of children and to protect their rights in every region, in particular those regions which are subject to violence, political unrest and poverty. The charter further recognizes that: (a) all children have a right to free and equal compulsory education within one department, as education is a right, not a privilege; (b) all children have a right to education, which is - be it formal or informal education - in their interest and which allows them to develop their talents; and, (c) all children have the right to adequate educational facilities and those facilities should be made accessible to children in difficult or violent situations.

The participants of the Civil Society Forum for promoting and protecting the rights of street children in North Africa and the Middle East determined the following challenges surrounding education for street children in Egypt (Consortium for Street Children, 2004): (a) families are not motivated to enroll their children in education for reasons of poverty, hidden costs (e.g. uniforms, textbooks), family disintegration, parental illiteracy and a general devaluation of education due to high rates of unemployment; (b) various features within the traditional education system act to push children out of school, including violence within the school, lack of trained teachers, overcrowding, poor facilities, inappropriate curricula, etc; (c) street children's access to educational facilities is poor in terms of locality, quality and timing (many street children need to work when non-formal classes take place); (d) education for street children is too theoretical and does not give adequate emphasis to more practical instruction, such as vocational training and income generation, which is often more important to a child's survival on the streets. It also neglects children's need to learn through recreation and sport; (e) prevalent cultural traditions and gender inequalities hinder the access and full participation of girls (whether street-associated or not) in formal and non-formal education; and, (f) the needs of children (particularly street children) with physical and mental disabilities are either marginalized or excluded altogether from education initiatives.

The participants of the Forum further put forward the following thematic recommendations (Consortium for Street Children, 2004): (a) enhance and develop the education systems to better suit the current and future developmental needs of children in the region with regard to employment and empowering them as socially responsible individuals capable of acting upon their changing situation; (b) government should implement or devise legislation protecting children within the education system from potentially harmful factors such as violence within the school, including corporal punishment, which may push them onto the streets; (c) develop the capacity of the social 
workers and psychologists within schools to reduce abuse; (d) street educator programs should be developed as an outreach educational facility for vulnerable children living and working on the streets. Legislation should be developed to protect these educators, who should themselves undergo training to the requisite standards; (e) active learning alternatives to the formal education system with appropriate curricula should be designed specifically targeting street and working children. This may include 'one-class schooling' where children learn for a flexible number of hours per day in accordance with their other commitments; and, (f) early childhood education opportunities should also be developed especially for vulnerable families.

\section{NGOs providing Education for street children}

Byrne (1998) asserted that the obligation to ensure both the children's right to education, and education for all, lies with national governments. Government organizations (GOs) all over the world acknowledge that education is a basic human right and that they are responsible for the provision of the latter. Even with the recognition of GOs, the phenomenon of children at risk still persists, hence, the need for NGOs' efforts to face such challenge.

Many NGOs have initiated community based-education programs with the primary objective of enabling street children and other marginalized groups to access education. Most education programs for street children are non-formal education (NFE) ventures. They are usually rehabilitative, compensatory and, above all, interventionist. NFE programs are often context specific and concentrate on the participants' true needs. The characteristics of NFE's include: (a) open access; (b) mainly provided by the community; (c) part time; (d) involves voluntary participation; (e) can accommodate mixed age groups; (f) short duration; ( $g$ ) teaching is delivered by paraprofessionals and volunteers; and, (h) it focuses on the less-fortunate and marginalized groups (Thomson, 2001).

A major characteristic of intervention programs for disadvantaged youth is the involvement of, and partnership with, other groups. In Brazil, for example, the 'Projeto Rio Crianca Cidade' involves religious 'Pastoral do Menor,' the military, the Ministry of Education, and the municipal secretariats for social development, health and education (Levenstein, 1996). In Namibia, the street children's program involves the ministries of health and social services, youth and sports, basic education, and culture and justice, as well as vocational training institutions, the Municipality of Windhoek, various sports associations, the National Commission for UNESCO and the University of Windhoek (UNICEF 1999). Partnerships in the Undugu Society of Kenya's education programs involve the Teachers' Service Commission, Nairobi City Council, the Kenya Institute of Education, Teacher Training College, Kindernothilfile of Germany, the Friends' Circle of Holland, the Department for International Development, African Development Assistance, National Children in Need Network, Kenya Alliance for Advancement of Children, and the community (Ouma, 2004, p. 72).

Shaeffer (1991, p. 6) offered several specific degrees of participation various actors could have in programs geared at children in especially difficult circumstances. These include participation: (a) as users of the services provided; (b) in the contribution of resources, materials and labor; (c) by attendance, for example, at parents' meetings; (d) through consultation on a particular issue; (e) in the delivery of a service; (f) as 
implementers of delegated powers; and, $(\mathrm{g})$ in real decision making at every stage, from identification of problems through to planning, implementation and evaluation.

The Egyptian government recognizes the important role of education in human resource development and that the government is responsible for the provision of education. Since the phenomenon of street children is not new to Egyptian society, government legislation has been dealing with the issue since 1826 when children less than twelve years of age were given legal protection and were not viewed as responsible for their actions. The application of juvenile laws seems to have coincided with the establishment of the Ministry of Social Affairs and the emergence of various NGOs, which tried to help decrease the magnitude of the phenomenon. The Ministry of Social Affairs targets the issue of street children through two main channels: (a) working with families in general, and developing preventive measures to tackle the problem, and (b) working directly with street children through various services, including those provided by the General Social Defense Department (ODCCP, 2002).

Most of the NGOs in Egypt took the form of "orphanages" as typical preventive and rehabilitative solutions to children exposed to delinquency, including lost children, foundlings, orphans, destitute children, or runaways. A quick review of the development of activities and programs which have been implemented to deal with the problem of street children during the last decade reveals that there has been a considerable increase in the number of NGOs dealing with the issue of street children (Hussein, 1998). NGOs in Egypt are now viewed by GOs as "partners in development" who should be contacted and cooperated with (El Badri, 2006).

As for direct intervention activities for children at risk, some of the services provided include Residential Care Institutions which provide full residence to children as well as many educational, vocational, recreational and other services until children reach a certain age and become able to depend on themselves, or until their family situation changes to the extent that children can return back to them (El Badri, 2006). Currently, the Ministry of Social Affairs has prepared a Draft Law for NGOs which defines ways of channeling assistance and funds to NGOs through local and international funding agencies. Despite these forms of cooperation, there is an immediate need for planned joint actions with all related organizations in the form of a national program. This is seen as vital to ensure effective results (El Badri, 2006; ODCCP, 2002).

As we have noted in this discussion, education for street children is emerging as a critical and urgent issue. Helping street children develop into self-fulfilling and effective citizens in the face of the grossly adverse street environment is a challenge that is complex.

\section{Methodology}

Data were collected using interview schedule and document analysis. Interviews were prepared for eight of the management staff of HVS that included the General Manager, four members of the board directors and three members in charge of education and training. Respondents were selected using the purposive sampling technique. Interviews were in Arabic and conducted at the office of HVS which is located at Nasr City in Cairo. The interviews helped collect data on partnership in HVS's education programs and the problems the education programs have encountered. Consent was 
sought to make audio tape recording of the interviews. Some of the subjects did not give their consent; therefore detailed notes were made during and after interviews. Document analyses were examined through published and unpublished sources. From the HVS, the following documents were important to the study: (a) reports on the education programs offered by HVS since its inception till 2006; and, (b) statistical records showing enrolment trends at HVS' education programs since its inception till 2006.

\section{Findings and Discussions}

Data were presented, discussed and analyzed according to the information obtained from interviews and document analyses. This is done under four themes as follows:

\section{Types of Education Offered by HVS}

For purposes of analysis, the education offered by HVS could be defined in three categories: (a) literacy classes, (b) training program, and (c) religious, social, cultural and recreational activities. Literacy classes that are connected to the Mokattam center for temporary residence were established in 1995. It was noticed that there were big numbers of school dropouts mainly resulting from the 1992 earthquake. This event demanded the government to resettle the affected families in the Mokattam area, which caused a disturbance due to life situations they were not accustomed to, and disruption from their previous life contexts. As a result, families became unable to satisfy their children's needs and this led them to fly away to the street, to spend most of their time there, where they were exposed to different hazards. School dropouts are therefore given these literacy classes. The services provided in the classes include all the scholastic subjects and the children are given two meals. A women's class was added in 1996 to help eliminate illiteracy among women and girls. Additionally, HVS led an innovative experimental new literacy program called "The Concentrated Language Encounter Technology (CLET)" which proved a great success. The Society is the first to apply it in Egypt and many have receiving training (Hope Village Society, 1995 - 2006).

In addition, a training program on a number of handicrafts is provided with the aim to help children join vocational programs at workshops and factories in the surrounding areas. This is also intended as a way to bring together these children with the surrounding community and help them to acquire a group of skills that will prepare them for future careers. The handicrafts taught include carpet weaving and hand-made silk decorative carpets, Khan El-Khalily crafts of mother of pearl works, and decorative candle-making. The trainees should not be under the age of fourteen (Hope Village Society, 1995 - 2006).

As to social, cultural, religious and recreational activities, HVS provides stable and warm family-like home care for the children, without overprotecting them, as they have to be prepared for independence later on. They are taught good values and proper behavior built on cooperation and self-reliance. The vital role culture plays in creating a civilized community is not absent and HVS offers great encouragement to children who have artistic talents to participate in cultural and artistic events. A magazine edited by the children is issued monthly allowing the children to express their ideas and show a talented effort in data gathering and presentation. The religious side of children's life is 
also important, as generally these youngsters lack the knowledge of religious doctrines and proper manners. Therefore, they are made accustomed to timely prayers and are taught to recite the Qur'an and to follow the good lessons deduced from the prophet's sayings. This is being taught by a specialized teacher (i.e. a "Shiekh") who is appointed by HVS for that aim. Recreational activities are varied for maintaining vitality and activity renewal. The children are provided with different programs such as monthly trips, fun parties, and summer camping. HVS also cares for the bodily fitness of the children to enhance their health through varied sport games like football and handball (Hope Village Society, 1995 - 2006). Thus, HVS plays a major role in providing education for street children in Egypt.

\section{Enrolment Trends at HVS's Education Programs since Their Inception}

According to HVS enrolment records, all the enrollees of HVS's education programs are either drop-outs/ push-outs of governmental schools or have never enrolled in a formal school at all. This points to a chronic wastage in primary school education, which, as noted by Black (1999), has profound consequences including a severe waste of human resources, an intergenerational perpetuation of poverty and underemployment, and an increased possibility of crime, violence, and social unrest. This exclusion from education is also, according to UNESCO (2000), a manifestation of a tragic violation of human rights; a violation that HVS's education programs try to mitigate through orienting children to literacy classes, training programs or formal education.

Since the establishment of HVS's education programs in1995, they have recorded fluctuating enrolment rates, as seen in Table 1. However, it could be said that there has been a general gradual increase in enrolment rates over the years. Moreover, the number of children enrolled in literacy classes is generally higher than those of vocational training and of governmental schools. Although the number of females is generally lower than that of males, their presence clearly indicates that the street children phenomenon concerns both sexes.

Table 1: Street Children Enrolled in HVS's Education Programs, 1995- 2006.

\begin{tabular}{|l|l|l|l|l|l|l|l|}
\hline \multirow{2}{*}{ Year } & \multicolumn{2}{l|l|l|l|l|}{ Locational training } & \multicolumn{2}{l|}{ Formal education } & \multirow{2}{*}{ Total } \\
\cline { 2 - 7 } & Males & Females & Males & Females & Males & Females & \\
\hline 1995 & 46 & 12 & 39 & 7 & 26 & 5 & 135 \\
\hline 1996 & 48 & 10 & 41 & 7 & 25 & 5 & 136 \\
\hline 1997 & 47 & 10 & 40 & 8 & 29 & 4 & 138 \\
\hline 1998 & 58 & 14 & 52 & 6 & 30 & 9 & 169 \\
\hline 1999 & 68 & 19 & 55 & 9 & 32 & 11 & 194 \\
\hline 2000 & 70 & 23 & 59 & 8 & 33 & 10 & 203 \\
\hline 2001 & 77 & 23 & 58 & 10 & 37 & 10 & 215 \\
\hline 2002 & 76 & 24 & 63 & 13 & 37 & 9 & 222 \\
\hline 2003 & 94 & 29 & 64 & 18 & 39 & 11 & 255 \\
\hline 2004 & 106 & 33 & 70 & 22 & 42 & 12 & 285 \\
\hline 2005 & 109 & 37 & 71 & 22 & 45 & 13 & 297 \\
\hline 2006 & 135 & 39 & 77 & 31 & 55 & 17 & 354 \\
\hline
\end{tabular}




\begin{tabular}{|l|l|l|l|l|l|l|l|} 
Total & 934 & 273 & 689 & 161 & 430 & 116 & 2603 \\
\hline
\end{tabular}

Source: HVS enrolment trends.

Partnership in HVS's Education Programs

Though Undugu in Kenya and 'Projeto Rio Crianca Cidade' in Brazil have quite a number of groups involved in their education programs for street children (Ouma, 2004; Levenstein, 1996), HVS has a limited number of groups involved in its programs, as is indicated in Table 2. For purposes of analysis, HVS's partners could be divided into three groups: (a) Egyptian Government; (b) NGOs; and (c) the community:

Table 2: Participants in HVS's Education Programs and Their Role

\begin{tabular}{|l|l|}
\hline Role & Partner \\
\hline $\begin{array}{l}\text { Providing books, teachers, technical assistance and } \\
\text { training items of the workshops. }\end{array}$ & $\begin{array}{l}\text { The National Department for Literacy } \\
\text { \& Adult Education }\end{array}$ \\
\hline Providing Financial assistance. & World Rotary \\
\hline $\begin{array}{l}\text { Offering financial contribution, acceptance of the } \\
\text { programs and care for the children. }\end{array}$ & Community \\
\hline
\end{tabular}

Source: Field data.

The Egyptian government acknowledges that education is a basic human right and that it is responsible for the provision of that education. Allowing HVS to run education programs was an obvious recognition of the need for concerted efforts to be made in the provision of education to all (ODCCP, 2002). The Egyptian Government's involvement in HVS's education programs has manifested itself through one association dealing with HVS. This association, as indicated in Table 2, is the National Department for Literacy \& Adult Education. Although the Egyptian Government participate in HVS's education programs through one association, its role is acceptable. The General Manager noted:

The Egyptian government is a key partner in implementing HVS's education programs. The books, teachers, technical assistance and training items of the workshops are provided by the government through the association of Literacy and Adult Teaching while HVS participates in the project by providing the place and the teachers' salaries.

The NGOs' involvement in HVS's education programs appears clearly through one agency which provides financial assistance. This agency, as indicated in Table 2, is the World Rotary. At present time, NGOs are not key partners of HVS in the provision of education for street children - a situation the management staff of this study considered good for sustainability. One of the management staff indicated:

HVS's education programs do not depend heavily on external donor assistance. That means that our programs are not at present restricting their financial obligations following diminishing financial assistance from donors, and should the donors pull out, our programs will not be forced to fold up. 
The management staff also felt that they had not done enough to encourage Egyptian local organizations to take part in their educational activities. One of the management staff noted:

As long as we have some worries of the external organizations, we should do our best to engage local organizations in our educational activities. However, we have done nothing in this concern yet. When I discussed this subject with the rest of staff, they asked me to make a paper about how can local organizations participate in our educational activities. We are going to discuss this paper in the next month.

It is important that the community be actively involved in the affairs of organizations such as HVS. Chattergee (1992) warned that unless those which the programs are designed to help are fully involved, the results are bound to be disappointing. Interviews with the management staff indicated four ways in which the community participated: (a) by offering financial contribution to HVS's education programs. It was noted that the management staff have not done enough to attract financial assistance from the local community, however many donors are offering their financial input. One member of the management staff supported this belief.

We know that the parents of street children are poor. We cannot ask for money from them. I think that there are many other people in our country who are able to offer financial support to our educational programs and actually some of them are doing. In fact, we have not done enough to attract other donors to our educational programs.

(b) by sending the children to HVS's education programs; this testifies to the community's acceptance and appreciation of HVS's education programs; (c) by taking care of the children - after lessons, children go back to their homes where they are fed, sleep and rest in preparation for the next day's work; and (d) by understanding and appreciation of HVS's education programs by local area politicians. Although the community's involvement in HVS's education programs is comparatively exhaustive, there are no volunteer teachers from the community.

\section{Problems that the HVS's Education Programs Encounter}

Interviews with management staff revealed that HVS's education programs were facing quite a number of problems which are listed below:

a) Syllabuses are not mainly designed for street children: Blunt (1994) noted that street children's attendance of education programs that do not fit their special needs is a terrible waste. Considering this problem, one member of the management staff said:

Our literacy education program is carried out through the Literacy and Adult Education Association (a governmental program), which provides books and teachers for the HVS. However, the syllabuses are not mainly designed for children with learning problems or children who cannot attend classes on regular basis (as in the case of street children). So, we are planning to start our own literacy education programs in the next period. 
b) Lack of trained teachers: for any educational enterprise to be successful, the quality and quantity of teachers is paramount. Though education programs for street children are usually fuelled largely by volunteer teachers (Oudenhoven, 1989; Easton et al. 1994), all teachers at HVS' education programs are employed (hired) by the literacy and adult education association and HVS pays their salary. According to the management staff, most teachers were unable to handle street children. Other teachers leave after a short while when they find a better opportunity in private or governmental schools. Thus, HVS are forced to accept untrained teachers.

c) Lack of relevant books and inadequate teaching and learning resources: without educational content that is relevant to current needs of street children and without efforts to improve learning resources, access may not serve the purposes intended nor provide the benefits expected (UNESCO, 1996). This was put by one member of the management staff in the following words:

Our teachers usually complain that they take a long time to search through a number of books to gather enough content to teach street children. Moreover, there is a lack of adequate teaching and learning resource.

d) Teaching learners with diverse abilities: education, as conceived, unfolds from the child's perspective and addresses each child's capacities and needs. This is even more important for street children, whose diversity of experiences requires well-focused attention on their unique needs and abilities (Panter-Brick, 2001). In this respect, one of the management staff said:

Our learners are completely different to the ones in the private or governmental schools. Here we have some learners who are already experiencing adolescence and some are not; some of them have gone to school and some have not. All these are put in the same class and we have to educate all of them.

e) Poor communication with other educational associations: the management staff members felt that there is a poor communication between HVS's education programs and other educational association. This problem was also noted by Easton et al. (1994). One member of the management staff put it as follows:

Our main partner in carrying out our educational programs is the Literacy and Adult Education association. I think that this is not enough. We must contact with other educational association. Such educational associations never come for us here to offer their help; it is us who have to go to them asking for their possible help in implementing our educational programs. I therefore discussed that poor communications between us and other educational associations with other management staff members. Now we are planning to expand our communications with the faculties of education and the National Centre of Educational Research.

f) Limited small-scale of vocational training: looking at this problem, a fundamental question asked by Leonardos $(1999$, p. 32) should be considered: "How relevant are the 
vocational training to the condition in real work places and how can individuals actually use the skills they have acquired in economically productive ways?" In this respect, one of the management staff members noted:

We have our own vocational training units, but on a limited small-scale, and aim mainly at developing the manual skills of street children rather than developing their vocational skills. We therefore need extra facilities and support to our vocational training programs. Moreover, we are planning to make use of the governmental vocational training centers.

g) Difficulties related to helping learners find employment: in some cases, the trainees are helped to find employment. In Brazil, this is a key ingredient of many programs for street children. For instance, Cruzada do Menor' has agreement with several state and local companies to employ some of the adolescents. The Centro de Referencia do Trabalho of 'Pastoral do Menor' works like labour exchange, offering jobs to children who attend apprenticeship courses. The 'Pastoral' tries to train the children in areas in which there is most demand for labour so that they are not unemployed when they complete their apprenticeship (Levenstein, 1996). One member of the management staff explained thus:

You know that unemployment rates in Egypt rose in the last five years even among the individuals of the university education level. In this respect, it is difficult to help the children to find employment once they finish their training. It is found that through helping the family economically, there might be a good chance for the learners to live with his family and enjoy the normal life he/she is deprived of. The Economical Rehabilitation Program is proposed to give loans to the chosen families to start small projects which generate stable incomes, on condition that the learner should be let to live normally with his family.

h) Lack of support and co-operation from learners' parents: this problem was also noted by Ouma (2004). The management staff accused learners' parents of showing no interest in their children school problems, such as low levels of understanding, poor concentration in class, and lateness. To illustrate this problem, one member of the management staff said:

Some of the learners' parents do not care about their children school work. Others never even know where their children are. In one particular case, a student went missing for about three weeks. When we contacted his parents to enquire about him where about, they admitted that they did not know where their son was. It was through other learners that we discovered his place. We were forced to get him back ourselves, for parents never seemed to care.

To assuage some of the above problems, the management staff suggested a number of solutions; which are: (a) HVS should establish its own educational programs that are mainly designed for street children; (b) preparation of pedagogical resources that are specific to HVS's programs; (c) more trained teachers; (d) revision of the curriculum; (e) more contact with other educational association for example, faculties of education 
and the National Centre of Educational Research; (f) extra facilities and support for vocational training; $(\mathrm{g})$ establishing a follow up program for former learners, therefore it can effectively assess how the learners perform in life after leaving HVS; (h) frequent meetings, with the parents of the learners; (h) frequent meetings, seminars and workshops for HVS staff to chart out the running of the programs; and (i) frequent guidance and counseling for the learners.

\section{Conclusions and Recommendations}

Street children in Egypt, and all over the world, have unique basic needs and consequently, different learning needs. HVS in Egypt plays a major role in providing education to street children, including helping them find employment once they finish training. While HVS provides an alternative education to street children in Egypt, syllabuses are not mainly designed for them, and, coupled with the lack of trained teachers and sufficient facilities, it is likely to result in the education programs offered as being of low quality. Cooperation between the Egyptian government and NGOs at HVS's education programs is not exhaustive. HVS's education programs are almost overly dependent on local donors. The problems that HVS education programs face are so overwhelming that, if not they responded to urgently; the problems may negate HVS's efforts.

The current study proffers the following recommendations: (a) literacy education of HVS should be mainly designed for children with learning problems or children who cannot attend classes or regular basis; (b) vocational training of HVS should address areas such as the pedagogy and the psychology of street children; (c) Egyptian government should provide more financial contributions to organizations that provide education to street children; (d) both GOs and NGOs should co-operate directly in projects aiming at dealing with the problem of street children in Egypt; (e) there is also an immediate need to engage other possible partners for HVS's education programs such as universities, religious organizations, community based education, women's organizations, other international organizations, and local business; (f) measures should be taken to encourage other organizations to initiate education programs mainly designed for street children as HVS alone is incapable of providing education for all street children in Egypt; and $(\mathrm{g})$ more research should be carried out in the area of pedagogy for street children. Beyond this study, it is recommended that other researchers focus on areas of curricula and teaching, competence of teachers who teach street children, and learning resources for street children.

\section{References}

Abdel-Nabi, A. (1994). Media handling of the problem of child vagrancy in Egypt. Institute of Childhood Studies: Ain Shams University, (In Arabic).

Abu Al-Nasr, M. (1992). The problem of street children in Cairo and Giza. Paper presented at the Second Scientific Conference in Social Work, Helwan University. (In Arabic).

Agnelli, S. (1986). Street Children-A Growing Urban Tragedy. London: Weidenfeld \& Nicolson. 
Aina, T. (1997). Globalization and social policy in Africa: Issues and research direction. Dakar: CODESRIA.

ANPPCAN. (1995). Hearing on street children in Kenya. Report on hearing held in Nairobi on 4 and 5 November 1994.

Bennani, W. (1996). Morocco's street children. Reuters, 24 September, Casablanca.

Bibars, I (1998). Street children in Egypt: From the home to the street to inappropriate corrective institutions. Environment and Urbanization, 10(1), 201-216.

Black, M. (1999). Basic education: A vision for the 21st century: Summary report. Florence: UNICEF-ICDC.

Blunt, A. (1994). Street children and their education: a challenge for urban educators. In N. Stromquist (ed.) Education in Urban Areas: Cross-National Dimensions. pp. 237-61. Westport: CT Praeger.

Bose, A. (1992). Disadvantaged urban child in India. Florence: UNICEF-ICDC.

Boyden, J. \& Mann, G. (2000). Children's risk, resilience and coping in extreme situations. Oxford: UK Background paper to the Consultation on Children in Adversity.

Brink, B. (2001). Working with the street children: Reintegration through education. Support for Learning, 16(2), 79-86.

Byrne, I. (1998). The Human Rights of Street and Working Children. London Intermediate Technol. Publ.

Caillosds, F. (1998). Education strategies for disadvantaged groups: Some basic issues. Paris: IIEP-UNESCO.

Casa Alianza. (2000). The general situation of the childhood in Mexico and Central America. Presentation to the Inter American Commission on Human Rights. Available at: http:// www-casa-alianza.org/es/streetchildren/general/docs/001011.phtml.

Chatterjee, A. (1992). India: The forgotten children of the cities. Florence: UNICEFICDC.

Connolly, M. and Ennew, J. (1996). Introduction: Children out of place. Childhood, Children Out of Place: Special Issue on Working Children, 3(2), 131-146.

Consortium for Street Children. (2004). The civil society forum for promoting and protecting the rights of street children in North Africa and the Middle East, held from 3 to 6 March, Cairo.

Dallape, F. (1996). Urban children: challenge and opportunity. Childhood, Children Out of Place: Special Issue on Working Children, 3(2), 283-294.

Easton, P., Klees, S., Milton, S., Papagiannis, G., Clowson, A., Dewees, T., Hobson, H., Lyons, B., and Munter, J. (1994). Asserting the educational rights of street and working children: lesson from the field. New York: UNICEF.

El Badri, A. (2006). Role of Government and NGOs in Addressing Problem of Street Children. Partnership in Development Research: Research Briefs. No. 35:1-8.

El-Kateb, E. (1998). Street children. Paper presented at the conference "Children in Difficult Social Circumstances.” Ahebaa El-Toufoula NGO, Cairo. (In Arabic).

Ennew, J. (1994). Street and working children: A guide to planning development. London: Save the Children. 
Glauser, B. (1990). Street Children: deconstructing a concept. In A. James and A. Prout (Eds.). Constructing and Reconstructing Childhood: Contemporary Issues in the Sociological Study of Childhood. (pp. 145-164). London: Falmer Press.

Hlatshwayo, V. (1997). Swaziland's street urchins. The Mail and Globe, 21 August. Mbabane.

Hope Village Society. (1995 -2006). Reports on the activities and programs of Hope Village Society. Cairo. (In Arabic).

Hussein, N. (1998). The phenomenon of street children: A field-research in Greater Cairo. Doctoral Dissertation, Ain Shams University, (In Arabic).

Kapadia, K. (1997). Children at risk in urban areas in India: a review. SCARO Briefing paper, No.6. Kathmandu: Save the Children (UK) South and Central Asia Reg. Office.

Koraim, A. (1998). The dimensions of the problem of street boys. Paper presented at the conference "Children in Difficult Social Circumstances." Ahebaa El-Toufoula NGO, Cairo. (In Arabic).

le Roux, J. (1996). The worldwide phenomenon of street children: conceptual analysis. Adolescence, 31(124), 965-71.

le Roux, J. \& Smith, C. (1998). Causes and characteristics of the street child phenomenon: a global perspective. Adolescence, 33(131), 683-88.

Leonardos, A. (1995). Effective strategies for and approaches for reaching street and working children through education: reviewing recent developments. Paris: UNESCO-IIEP.

Levenstein, S. (1996). Educating street children: Innovative ideas and programs in Brazil. South African Journal of Education, 16(1), 45-50.

Lusk, M. (1989). Street children programs in Latin America. Journal of Sociology and Social Welfare, 16(1), March.

Moss, P., Dillon, J. and Statham, J. (2000). The 'child in need' and 'the rich child': discourses, constructions and practice. Critical Social Policy, 20(2), 233-54

ODCCP (2002). Rapid situation assessment of street children in Cairo and Alexandria. United Nations: ODCCP Studies on Drugs and Crimes.

Oudenhoven, N. (1989). Children at Risk and community response. Paris: UNESCO; UNICEF; WFP.

Ouma, W. (2004). Education for street children in Kenya: The role of the Undugu Society. Paris: International Institute for Educational Planning.

Panter-Brick ,C. (2001). Street children: cultural concerns. In N.J. Smelser and P.B. Baltes (Eds) International Encyclopedia of the Social and Behavioral Sciences, 22(151), 54-57. Oxford: Elsevier.

Sedik, A. (1995). Experiences with the problem of street children in Egypt. Cairo: Center for Child Protection and Rights, (In Arabic).

Shaeffer, S. (1991). A framework for collaborating for educational change. Paris: IIEPUNESCO.

Shanahan, P. (1998). The alternative Africa street children in Accra, Ghana: their place at the global table. Paper presented in Washington conference.

Shanahan, P. (2003). Streets versus elites: Tensions, trade-offs and treaties with street children in Accra, Ghana. Children Youth and Environments, 13(1). 
Shorter, A. and Onyancha, E. (1999). Street children in Africa: A national case study. Nairobi: Pauline's Publication.

Smith, K. 1997. Street kids find hope at the end of the road. Mexico: El Universal, El Gran Diario de Mexico.

The Children's Charter of South Africa. (1992). Resolutions of the international children's summit held from 27 May to 1 June 1992, Cape Town.

The General Egyptian Association for Child Protection. (1999). Care for street children in Alexandria. Alexandria: Unpublished Report, (in Arabic).

Thompson, E. (2001). Non-formal education in urban Kenya: Findings of a study in Kisumu, Mombasa and Nairobi. London: Commonwealth Secretariat. Available at: http://www.adeanet.org/wgnfe/publications/kenya thomposon.pdf

UNESCO. (1996). Education for all: achieving the goal. Final Report. Paris: UNESCO. Available

at: http://www.unesco.org/education/efa/ed_for_all/background/efinalrep96.pdf.

UNESCO. (2000). Inclusive education and education for all: A challenge and vision. Paris: UNESCO.

UNICEF. (1999). The state of the world's children 1999. New York: UNICEF.

Velis, J. (1995). Blossoms in the dust: Street children in Africa. Paris: UNESCO.

WHO. (2002). Working with street children: Monitoring and evaluation of a street children project. World Health Organization. Geneva.

Wright, J. (1990). Homelessness is not healthy for children and other living things. Child Youth Service, 14(1), 65-88.

Young, S. (1995). Open season on Nairobi's Street kids. Humanist, 1 November. New York. 